\title{
In Vitro efficacy of antimicrobial extracts against the atypical ruminant pathogen Mycoplasma mycoides subsp. capri
}

\author{
Amanda V Arjoon ${ }^{1}$, Charlotte V Saylor ${ }^{1}$ and Meghan May ${ }^{1,2^{*}}$
}

\begin{abstract}
Background: Mycoplasmosis is a common infection in human and veterinary medicine, and is associated with chronic inflammation and high morbidity. Mycoplasma species are often intrinsically resistant to many conventional antimicrobial therapies, and the resistance patterns of pathogenic mycoplasmas to commonly used medicinal (antimicrobial) plant extracts are currently unknown.
\end{abstract}

Methods: Aqueous extracts, ethanol extracts, or oils of the targeted plant species and colloidal silver were prepared or purchased. Activity against the wall-less bacterial pathogen Mycoplasma mycoides subsp. capri was determined and compared to activities measured against Escherichia coli and Bacillus subtilis. Antimicrobial susceptibility testing was performed by broth microdilution assays. The lethal or inhibitory nature of each extract was determined by subculture into neat growth medium.

Results: Growth of M. mycoides capri, E. coli, and B. subtilis was inhibited by elderberry extract, oregano oil, ethanol extract of oregano leaves, and ethanol extract of goldenseal root. No inhibition was seen with aqueous extract of astragalus or calendula oil. Growth of M. mycoides capri and B. subtilis was inhibited by ethanol extract of astragalus, whereas growth of E. coli was not. Similarly, M. mycoides capri and E. coli were inhibited by aqueous extract of thyme, but B. subtilis was unaffected. Only B. subtilis was inhibited by colloidal silver. Measured MICs ranged from $0.0003 \mathrm{mg} / \mathrm{mL}$ to $3.8 \mathrm{mg} / \mathrm{mL}$. Bacteriostatic and bactericidal effects differed by species and extract.

Conclusions: The atypical pathogen M. mycoides capri was sensitive to extracts from many medicinal plants commonly used as antimicrobials in states of preparation and concentrations currently available for purchase in the United States and Europe. Variation in bacteriostatic and bactericidal activities between species and extracts indicates that multiple effecter compounds are present in these plant species.

\section{Background}

Atypical bacteria lack or produce aberrant forms of cellular components that characterize most bacterial species. Members of the genus Mycoplasma lack cell walls, do not synthesize nucleotides or amino acids, express an unusual form of RNA polymerase, and certain species produce atypical ribosomes [1]. These biological features make mycoplasmas intrinsically resistant to many antibiotics, and successful treatment options are restricted to tetracyclines, macrolides, and fluoroquinolones. Mycoplasma

\footnotetext{
* Correspondence: mmay@towson.edu

'Department of Biological Sciences, Fisher College of Science and Mathematics, Towson University, Towson, MD, USA

${ }^{2}$ Department of Biological Sciences, Towson University, 8000 York Road, Towson, MD 21252, USA
}

infections are a grave concern in veterinary medicine, where they are associated with detrimental and economically burdensome infections in production animals including cattle, goats, swine, chickens, and turkeys [2]. Human mycoplasmosis is associated with numerous clinical manifestations, most notably community acquired pneumonia and nongonococcal urethritis [3,4].

The in vitro inhibitory effects of goldenseal (Hydrastis canadensis), huang qi (Astragalus membranaceus), oregano (Origanum vulgare), thyme (Thymus vulgaris), elderberry (Sambucus nigra), and calendula (Calendula officinalis) have been observed and reported for true gram-positive and gram-negative bacteria (Table 1) [5-10]. Their effect on wall-less atypical bacteria such as mycoplasmas is virtually unexplored. A small number of ethnopharmacological 
Table 1 Plant sources used in this study ${ }^{a}$

\begin{tabular}{llllll}
\hline Plant & Common name & Active compound & Chemical family & Extract spectrum & Reference \\
\hline Hydrastis canadensis & Goldenseal & Berberine & Alkaloid & G+, G- & Unk \\
\hline Astragalus membranaceus & Astragalus & Polysaccharides (?) & Polysaccharide & Unt & {$[9]^{\text {b }},[13]$} \\
\hline Origanum vulgare & Oregano & Carvacrol, Thymol & Phenol & G+, G- & {$[6,14]$} \\
\hline Thymus vulgaris & Thyme & Carvacrol & Phenol & G+, G- & {$[10]$} \\
\hline Sambucus nigra & Elderberry & Tannins, lupeol & Flavonoid, Triterpene & G+, G- & {$[7,15,16]$} \\
\hline Calendula officinalis & Calendula & Unk & N/A & Unk & {$[5]$} \\
\hline
\end{tabular}

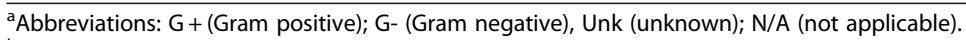

${ }^{\mathrm{b}}$ Reference is a review article.

studies have explored antimycoplasmal effects of medicinal plants used in Jordan [11] and Nigeria [12] but the impact of botanicals widely used in the United States and Europe on mycoplasmas remains unknown. The lack of classical antimicrobial targets make mycoplasmas intrinsically resistant to many antibiotics [1], and it is unknown if they are similarly resistant to crude and purified extracts from plants commonly used to treat infections in botanical medicine. We examined commercial extracts of the $H$. canadensis, A. membranaceus, O. vulgare, T. vulgaris, S. nigra, and C. officinalis for efficacy against the small ruminant pathogen Mycoplasma mycoides subsp. capri. Whole plant extracts and colloidal silver (commercial or freshly prepared) were used at retail concentrations and preparations to better simulate the conditions under which these compounds would be utilized to treat infection in vivo. The aim of this study is to determine the efficacy of several commercial and fresh extracts of plants commonly used in botanical medicine (Hydrastis canadensis, Astragalus membranaceus, Origanum vulgare, Thymus vulgaris, Sambucus nigra, and Calendula officinalis) against atypical pathogenic bacterial species that lack many common antimicrobial targets, represented here by $M$. mycoides capri. Escherichia coli and Bacillus subtilis were used as a standard for comparison with eubacterial species in our experimental setting.

\section{Methods}

\section{Bacterial strains and culture conditions}

Mycoplasma mycoides subspecies capri strain GM12 was cultured in American Type Culture Collection (ATCC) medium 988 (SP-4) containing 20\% v/v fetal bovine serum and $1 \% \mathrm{w} / \mathrm{v}$ D-glucose. Escherichia coli strain DH5 $\alpha$ and Bacillus subtilis strain ATCC 6051 (Marburg $^{\mathrm{T}}$ strain) were cultured in modified trypticase soy (mT-soy) medium supplemented with $0.002 \% \mathrm{w} / \mathrm{v}$ phenol red, $1 \% \mathrm{w} / \mathrm{v} \mathrm{D}$-glucose, and $1 \% \mathrm{w} / \mathrm{v} \mathrm{D}$-mannitol to ensure colorimetric visualization of growth. All cultures were incubated at $37^{\circ} \mathrm{C}$.

\section{Plant extracts}

Commercial preparations (aqueous, ethanol, or oil) of $H$. canadensis, A. membranaceus, O. vulgare, T. vulgaris, S. nigra,

Table 2 Extract properties ${ }^{a}$

\begin{tabular}{|c|c|c|c|c|}
\hline Extract & Manufacturer & Concentration $(\mathrm{mg} / \mathrm{mL})^{b}$ & Solvent & Additional components ${ }^{c}$ \\
\hline Astragalus-Aq & N/A & 100 & Water & None \\
\hline Astragalus-ETOH & N/A & 100 & 95\% ethanol & None \\
\hline Astragalus-Com & Gaia Herbs & 500 & $50 \%$ ethanol & None \\
\hline Goldenseal-Aq & N/A & 100 & Water & None \\
\hline Goldenseal-ETOH & N/A & 100 & 95\% ethanol & None \\
\hline Goldenseal-Com & Gaia Herbs & $10^{d}$ & $65 \%$ ethanol & None \\
\hline Elderberry-G & Gaia Herbs & 380 & Water & $\mathrm{C}_{12} \mathrm{H}_{22} \mathrm{O}_{11}$, Acerola extract \\
\hline Elderberry-365 & 365 Everyday Value & 100 & Water & $\mathrm{C}_{3} \mathrm{H}_{8} \mathrm{O}_{3}, \mathrm{C}_{6} \mathrm{H}_{7} \mathrm{KO}_{2}$ \\
\hline Oregano-LE & Gaia Herbs & 333 & $65 \%$ ethanol & None \\
\hline Oregano oil & North American Herb and Spice & 1667 & Olive oil & None \\
\hline Thyme & Nature's Answer & 1000 & $15 \%$ ethanol & $\mathrm{C}_{3} \mathrm{H}_{8} \mathrm{O}_{3}$ \\
\hline Calendula & Eclectic Institute & 945 & Olive oil & None \\
\hline Colloidal silver & Source Naturals & 0.03 & Water & None \\
\hline
\end{tabular}

${ }^{a}$ Abbreviations: N/A (not applicable/extracts produced for this study); Aq (aqueous extract); ETOH (ethanol extract); Com (commercial extract); LE (leaf extract).

${ }^{\mathrm{b}}$ Starting concentrations are those reported for commercial products, and were not normalized to maximize relevance to common use practices.

${ }^{c}$ Role of additional components: $\mathrm{C}_{12} \mathrm{H}_{22} \mathrm{O}_{11}$ (sucrose)-sweetener; $\mathrm{C}_{3} \mathrm{H}_{8} \mathrm{O}_{3}$ (glycerol)-texture, sweetener; $\mathrm{C}_{6} \mathrm{H}_{7} \mathrm{KO}_{2}$ (potassium sorbate)-antifungal preservative; Acerola extract-ascorbic acid supplementation, anti-inflammatory properties, additional antimicrobial properties ${ }^{28}$.

${ }^{\mathrm{d}}$ Concentration reported by the manufacturer refers to total alkaloids rather than plant material. 
and $C$. officinalis are described in Table 2. Reported concentrations in $\mathrm{mg} / \mathrm{mL}$ reflect a w/v measurement of crude plant material to solvent. Aqueous and ethanol extracts of $H$. canadensis and $A$. membranaceus were prepared as previously described [17] (referred to as "fresh" or "freshly prepared"). Briefly, $10 \mathrm{~g}$ dried, ground plant material was suspended in $100 \mathrm{~mL}$ of molecular-grade water or $95 \%$ ethanol. Cellular materials were disrupted by sonication, and suspensions were rapidly shaken on an orbital shaker for 48 hours. Material in suspension was removed by repeated centrifugation at 4,000 RPM followed by vacuum filtration through a $0.45 \mu \mathrm{M}$ pore nitrocellulose membrane. Fresh and commercial extracts were stored at $4^{\circ} \mathrm{C}$.

\section{Antimicrobial susceptibility testing}

Stock cultures of M. mycoides capri, E.coli, and B. subtilis were diluted to 0.5 McFarland standard in sterile SP-4 or mT-soy medium. Minimum inhibitory concentrations (MIC) were determined by broth microdilution as previously described [18] using SP-4 or mT-soy as the diluents for serial 10-fold dilutions of extracts. $10 \%$ solutions of molecular grade water, 95\% ethanol (i.e., 9.5\% final concentration), and olive oil were inoculated with each species to control for the effect of plant extract solvents. Starting concentrations of each extract ranged from 1667 to $0.03 \mathrm{mg} / \mathrm{mL}$ and are reported in Table 2 . Broth microdilution assays were incubated for 18 hours at $37^{\circ} \mathrm{C}$. Bacterial growth was noted by acidification of the medium observed colorimetrically by shifting of the $\mathrm{pH}$ indicator phenol red. The bacteriostatic versus bactericidal nature of the extracts was determined by subculture from wells containing inhibitory dilutions into neat SP-4 or mT-soy medium (broth and agar) at $37^{\circ} \mathrm{C}$. Bactericidal activity of an extract was noted after incubation for 7 days and an absence of colonies on agar plates. Minimum bacteriostatic concentrations (MBCs) were recorded. All susceptibility tests were performed three distinct times.

\section{Results and discussion}

The efficacy of commercial and fresh extracts of plants commonly used in botanical medicine to treat infection (Hydrastis canadensis, Astragalus membranaceus, Oreganum vulgare, Thymus vulgaris, Sambucus nigra, and Calendula officinalis) and colloidal silver against an atypical pathogenic bacterial species that lacks many common antimicrobial targets was examined. Representative species were selected for analysis based on precedent in antimicrobial assessments of botanical extracts (gram negative species $E$. coli and gram positive species B. subtilis) or in vitro growth characteristics (atypical species $M$. mycoides capri) $[19,20]$. Mycoplasmas are notoriously fastidious, but $M$. mycoides capri grows well in axenic culture and thus is ideal for in vitro analysis. Microdilution was selected over disk-diffusion because several recent studies have reported greater experimental sensitivity with broth microdilution [21,22]. Intraspecies diversity in resistance to many conventional antibiotics has been noted for $M$. mycoides capri and may also exist for the included antimicrobial extracts [23,24], therefore the use of a single strain represents a limitation of this work. Future studies including numerous strains are needed prior to recommending a standard concentration for treatment with extracts; however, this study represents an essential first step in establishing a baseline expectation for susceptibility using strain GM12.

We found a wide range of resistance and sensitivities with the compounds tested, two of which conflicted with previous findings (Table 3) indicating higher sensitivity of gram positive bacteria to goldenseal alkaloids (analogous to our commercial goldenseal) than of E. coli [25], and sensitivity of $E$. coli to colloidal silver by qualitative methods [26]. Growth of M. mycoides capri, E. coli, and $B$. subtilis was inhibited by all tested elderberry extracts, oregano oil, ethanol extract of oregano leaves, and fresh ethanol extract of goldenseal root. No inhibition was seen with aqueous extract of astragalus or calendula oil. Growth of $M$. mycoides capri and B. subtilis was inhibited by fresh ethanol extract of astragalus, whereas growth of E. coli was not. Similarly, M. mycoides capri and $E$. coli were inhibited by a commercial ethanol extract of thyme, but B. subtilis was unaffected. Only $B$. subtilis was inhibited by colloidal silver, and only $M$. mycoides capri was inhibited by fresh aqueous extract of goldenseal root. No inhibition was observed for any species with the extract solvents (i.e., molecular grade water, 95\% ethanol, or olive oil).

While inhibition of $B$. subtilis and M. mycoides capri was observed for the fresh astragalus ethanol extract, the commercial ethanol extract and the fresh aqueous extract were ineffective. Our data suggest that the antimicrobial component of A. membranaceus is not water-soluble, and that the commercial preparation tested does not retain the component. While we did not observe any inhibition with calendula oil, other studies have documented its positive contribution to wound healing [27-30]. Calendula is associated with lymphocyte activation [15], angiogenesis [30], and alleviation of irritations [31], so it is plausible that its role in healing is due primarily to immune modulation and stimulation of tissue repair rather than antimicrobial activity.

The MICs of compounds that exhibited growth inhibition are presented in Table 3. Measured MICs ranged from $0.0003 \mathrm{mg} / \mathrm{mL}$ to $3.8 \mathrm{mg} / \mathrm{mL}$. Commercial ethanol extracts of astragalus differed in their measured MICs from our laboratory-prepared ethanol extracts for $B$. subtilis and $M$. mycoides. Commercial ethanol extracts of goldenseal root differed from our laboratory-prepared ethanol extracts for all three species tested (Table 3). 
Table 3 Minimum inhibitory and bacteriostatic concentrations ${ }^{a}$

\begin{tabular}{|c|c|c|c|c|c|c|}
\hline \multirow[t]{2}{*}{ Extract } & \multicolumn{2}{|c|}{ E. coli } & \multicolumn{2}{|c|}{ B. subtilis } & \multicolumn{2}{|c|}{ M. mycoides capri } \\
\hline & $\mathrm{MIC}(\mathrm{mg} / \mathrm{mL})$ & $M B C^{b}(\mathrm{mg} / \mathrm{mL})$ & MIC (mg/mL) & $M B C^{b}(\mathrm{mg} / \mathrm{mL})$ & $\mathrm{MIC}(\mathrm{mg} / \mathrm{mL})$ & $M B C^{b}(\mathrm{mg} / \mathrm{mL})$ \\
\hline Astragalus-Aq & $>10$ & N/A & $>10$ & N/A & $>10$ & N/A \\
\hline Astragalus-ETOH & $>10$ & N/A & 0.001 & 0.001 & 1.0 & $\mathrm{BC}$ \\
\hline Astragalus-Com & $>50$ & N/A & $>50$ & N/A & $>50$ & N/A \\
\hline Goldenseal-Aq & $>10$ & N/A & $>10$ & N/A & 0.05 & 0.5 \\
\hline Goldenseal-ETOH & 1.0 & 1.0 & 1.0 & $\mathrm{BC}$ & 1.0 & 1.0 \\
\hline Goldenseal-Com ${ }^{c}$ & 0.1 & BC & $>1$ & N/A & $>1$ & $\mathrm{~N} / \mathrm{A}$ \\
\hline Elderberry-G & 0.0038 & 0.0038 & 3.8 & 3.8 & 0.38 & 0.38 \\
\hline Elderberry-365 & 0.1 & $\mathrm{BC}$ & $>10$ & N/A & 0.001 & BC \\
\hline Oregano-LE & 0.033 & BC & 0.00033 & $B C$ & 0.033 & $B C$ \\
\hline Oregano oil & 0.167 & BC & 0.0167 & BC & 0.092 & 0.167 \\
\hline Thyme & 1.0 & $\mathrm{BC}$ & $>100$ & N/A & 0.5 & $\mathrm{BC}$ \\
\hline Calendula & $>95$ & N/A & $>95$ & N/A & $>95$ & N/A \\
\hline Colloidal silver & $>0.003$ & N/A & 0.0003 & 0.0003 & $>0.003$ & N/A \\
\hline Water & $\mathrm{NI}$ & $\mathrm{N} / \mathrm{A}$ & $\mathrm{NI}$ & N/A & $\mathrm{NI}$ & N/A \\
\hline $95 \%$ Ethanol & $\mathrm{NI}$ & N/A & $\mathrm{NI}$ & N/A & $\mathrm{NI}$ & $\mathrm{N} / \mathrm{A}$ \\
\hline Olive oil & $\mathrm{NI}$ & $\mathrm{N} / \mathrm{A}$ & $\mathrm{NI}$ & $\mathrm{N} / \mathrm{A}$ & $\mathrm{NI}$ & $\mathrm{N} / \mathrm{A}$ \\
\hline
\end{tabular}

${ }^{\mathrm{a}} \mathrm{N}=3$ replicates; MIC/MBC concentrations reflect mean values across trials. Abbreviations: N/A (not applicable); $\mathrm{BC}$ (bactericidal); $\mathrm{NI}$ (no inhibition by solvents at the lowest dilution [1:10]). Efficacious compounds with a measureable inhibitory concentration or bactericidal activity are bolded.

${ }^{b}$ Columns marked N/A or BC indicate that MBCs could not be determined due to lack of inhibition (N/A) or bactericidal activity (BC).

${ }^{\mathrm{C} C o n c e n t r a t i o n}$ reflects total alkaloid content.

Similarly, two distinct brands of elderberry extract (Gaia Herbs and 365 Everyday Value) had measurable differences in MIC for all three species (Table 3). Finally, whole oregano oil and ethanol extract of oregano leaf showed measurably different MICs for all three organisms (Table 3). The subculture of inhibited wells into neat SP-4 or mT-soy medium indicated a range of bacteriostatic and bactericidal effects that differed by species and extract (Table 4). Aqueous extract of goldenseal and one preparation of elderberry extract (Gaia Herbs) were uniformly bacteriostatic across inhibited species, and oregano oil, the second preparation of elderberry extract (365 Everyday Value), and thyme extract were uniformly bactericidal across inhibited species. The remaining extracts were static for certain species and lethal for others (Table 4).

S. nigra (elderberry) has been traditionally used to treat influenza, but a small number of additional studies show that this compound inhibits growth of gram positive and gram negative bacteria [25,32]. Inhibition was observed for both formulations of elderberry used in this study, but direct comparisons are difficult to make due to additional components in the formulation. The Gaia Herbs formulation contained acerola extract, which has also been reported to have antimicrobial activity [14]. However, Motohashi et al. reported the acerola was ineffective against all gram negative bacteria tested, while gram positive bacteria were sensitive. We found the MIC of the gram negative $E$. coli was 100-fold lower than the MICs of the gram positive $B$. subtilis and the atypical M. mycoides capri for this formulation of elderberry, indicating that acerola was not a major component of the observed inhibition. The antifungal and antibacterial preservative potassium sorbate $\left(\mathrm{C}_{6} \mathrm{H}_{7} \mathrm{KO}_{2}\right)$ was added to the 365 Everyday Value formulation of elderberry. The impact of $\mathrm{C}_{6} \mathrm{H}_{7} \mathrm{KO}_{2}$ was apparent from the post-inhibition analysis, where the 365 Everyday Value formulation was found to be bactericidal and the Gaia

Table 4 Post-inhibition analysis ${ }^{a}$

\begin{tabular}{lccc}
\hline Compound & E. coli & B. subtilis & M. mycoides capri \\
\hline Astragalus-Aq & resistant & resistant & resistant \\
\hline Astragalus- ETOH & resistant & bacteriostatic & bactericidal \\
\hline Astragalus-com & resistant & resistant & resistant \\
\hline Goldenseal-Aq & resistant & resistant & bacteriostatic \\
\hline Goldenseal-ETOH & bacteriostatic & bactericidal & bacteriostatic \\
\hline Goldenseal-com & bactericidal & resistant & resistant \\
\hline Elderberry (365) & bactericidal & resistant & bactericidal \\
\hline Elderberry (G) & bacteriostatic & bacteriostatic & bacteriostatic \\
\hline Oregano leaf & bactericidal & bactericidal & bactericidal \\
\hline Oregano oil & bactericidal & bactericidal & bacteriostatic \\
\hline Colloidal Silver & resistant & bactericidal & bactericidal \\
\hline Thyme & bactericidal & resistant & bactericidal \\
\hline Calendula & resistant & resistant & resistant
\end{tabular}

aDefinition of terms: "resistant"-species was resistant to the compound; no analysis performed; "bacteriostatic": compound was shown to be bacteriostatic by growth upon subculture; "bactericidal": compound was shown to be bactericidal by lack of growth upon subculture. $\mathrm{N}=2$ replicates. 
Herbs preparation was found to be bacteriostatic. The antibacterial effect of $\mathrm{C}_{6} \mathrm{H}_{7} \mathrm{KO}_{2}$ is bactericidal [33], and so the presence of this preservative likely contributes to the analytic discrepancy and the inhibitory effect of the 365 Everyday Value preparation. While inhibition was observed for E. coli and M. mycoides capri with this preparation, the MIC was 2-fold higher for E. coli. In contrast, the MIC was 100-fold lower for M. mycoides capri, potentially indicating a greater sensitivity of atypical bacteria to the preservative $\mathrm{C}_{6} \mathrm{H}_{7} \mathrm{KO}_{2}$. Susceptibility testing using $\mathrm{C}_{6} \mathrm{H}_{7} \mathrm{KO}_{2}$ alone was not performed, but would confirm this indication. In further contrast, B. subtilis was resistant to the 365 formulation of elderberry at concentrations above the MIC measured for the Gaia Herbs formulation indicating that either 1.) the differential in MIC for $B$. subtilis can be attributed to the anti-gram positive effects of acerola; 2.) the efficacy of elderberry's antimicrobial components is sensitive to shelf life; or 3.) elderberry and acerola act synergistically against $B$. subtilis in a way that elderberry and $\mathrm{C}_{6} \mathrm{H}_{7} \mathrm{KO}_{2}$ do not. In any case, it is clear that there are marked differences in in vitro efficacy between these formulations for all three representative types of bacteria.

Comparisons between commercial and freshly prepared ethanol extracts of astragalus and goldenseal root lend support to the notion of shelf life being an underappreciated problem, though differences in processing or preparation have not been accounted for. Fresh astragalus extract inhibited growth of B. subtilis and $M$. mycoides capri, while the commercial extract was ineffective against all three species. Similarly, the fresh ethanol extract of goldenseal root inhibited the growth of all three species, while B. subtilis and M. mycoides capri were completely resistant to the commercial extract. Curiously, E. coli had a 10-fold lower MIC for the commercial extract, but this is likely due to the reported concentration reflecting total alkaloid content rather than the dry weight of the whole root as was the case for the fresh ethanol extract. The alkaloid berberine is recognized as the major antibacterial component of goldenseal root [8], indicating that the commercial extract should intrinsically have a lower measured MIC than the fresh ethanol extract. Room-temperature storage of commercial and freshly prepared extracts with periodic measurements of the MICs for each would appropriately assess the scale of this problem.

Our data collected from oregano preparations and our post-inhibition analysis support findings from previous studies [17] indicating that commercial extracts of medicinal plants contain multiple antimicrobial compounds. Ethanol extract from oregano leaves had lower MICs than oil emulsion of whole oregano for all three species, and this difference was remarkably pronounced for $B$. subtilis and $M$. mycoides capri. This difference likely stems from 1.) differential solubility of antibacterial compounds in oil versus ethanol, 2.) components present in the stem and root acting antagonistically to the effect exhibited by components in the leaves, or both. Lambert et al. reported that multiple antibacterial compounds are present in oregano plants [34], but this work was later contradicted by Peñalver et al. who associated the activity exclusively with the phenolic compound carvacrol [35]. However, there is greater evidence for the presence of multiple compounds in the form of findings showing a greater antimicrobial effect of oregano oil than of purified carvacrol [36]. Similarly, our findings of an extract being bacteriostatic for one species and bactericidal for another (as was the case for oregano leaf extract and fresh ethanol extracts of goldenseal root and astragalus) suggests multiple components within the same extracts exhorting different biological effects. This likely explains the unexpected finding of a wide range of sensitivity by $M$. mycoides capri when intrinsic antimicrobial resistance is predictable [1].

Our data indicate that commercial preparations of medicinal plants are predictably variable in their MIC and antibacterial spectrum. Because most are commercial extracts, however, the concentrations used are relevant to common usage scenarios despite the extracts having potential to be inhibitory at higher concentrations. Perhaps surprisingly the wall-less, atypical species $M$. mycoides capri was not limited in its sensitivity profile as compared to the eubacterial species E. coli and B. subtilis.

\section{Conclusion}

Interest in botanical medicine has led to widespread availability of antimicrobial plant extracts in the United States. We found a wide range of resistance and sensitivities with the compounds tested, the majority of which were consistent with previous findings for eubacteria. In the case of thyme ethanol extract, our findings complement a previous report describing the effects of an aqueous extract [37]. The in vitro efficacy of these extracts at their available concentrations on atypical bacteria is vastly understudied, and our study represents an important first step in establishing the efficacy of these compounds as botanical treatments for mycoplasmosis. Further exploration into the toxicity, bioavailability, pharmacokinetics, and ultimately the in vivo efficacy against mycoplasmosis of these extracts will provide evidence for their potential use as treatments or for the disinfection of agricultural or clinical fomites such as milking equipment. Based on the measured antimicrobial effects of the medicinal plants we studied, common commercial preparations of astragalus (ethanol extracts), goldenseal root (aqueous or ethanol extracts), elderberry, oregano (leaf extracts or essential oil), and thyme have potential to be primary or ancillary treatments for mycoplasmosis, and further study in vivo is required. 


\section{Competing interests}

The authors declare that they have no competing interests

\section{Authors' contributions}

AVA and MM carried out experimental procedures. MM and CVS designed the study, drafted, and revised the manuscript. Authors read and approved the final manuscript.

\section{Acknowledgements}

This work was supported by intramural funds from Towson University. We thank J. Canter, D. Dunne, M. Feng, J. Jones, and T. Kaur for critical review of this manuscript.

Received: 3 April 2012 Accepted: 24 September 2012

Published: 2 October 2012

\section{References}

1. Bébéar C, Kempf I: Antimicrobial Therapy and Antimicrobial Resistance. In Mycoplasmas: Molecular Biology, Pathogenicity, and Strategies for Control. Edited by Blanchard A, Browning GF. Norfolk, NR United Kingdom: Horizon Biosciences; 2005:535-568.

2. May M, Arjoon AV, Canter JA, Dunne DM, Terrell B: Mycoplasmology. In Encyclopedia of Life Support Systems [developed under the auspices of the United Nations Educational, Scientific, and Cultural Organization]. Edited by Kirby R, Downing TG. Oxford United Kingdom: Eolss Publishers; 2012. online.

3. Atkinson TP, Balish MF, Waites KB: Epidemiology, clinical manifestations, pathogenesis and laboratory detection of Mycoplasma pneumoniae infections. FEMS Microbiol Rev 2008, 32:956-973.

4. Taylor-Robinson D, Jensen JS: Mycoplasma genitalium: from Chrysalis to multicolored butterfly. Clin Microbiol Rev 2011, 24:498-514.

5. Dumenil G, Chemli R, Balansard C, Guiraud H, Lallemand M: [Evaluation of antibacterial properties of marigold flowers (Calendula officinalis L.) and mother homeopathic tinctures of $C$. officinalis $L$. and $C$. arvensis $L$. (author's transl)]. Ann Pharm Fr 1980, 38:493-499.

6. Eng W, Norman R: Development of an oregano-based ointment with anti-microbial activity including activity against methicillin-resistant Staphlococcus aureus. J Drugs Dermatol 2010, 9:377-380.

7. Krawitz C, Mraheil MA, Stein M, Imirzalioglu C, Domann E, Pleschka S, Hain T: Inhibitory activity of a standardized elderberry liquid extract against clinically-relevant human respiratory bacterial pathogens and influenza $\mathrm{A}$ and B viruses. BMC Complement Altern Med 2011, 11:16.

8. Scazzocchio F, Cometa MF, Tomassini L, Palmery M: Antibacterial activity of Hydrastis canadensis extract and its major isolated alkaloids. Planta Med 2001, 67:561-564.

9. Sinclair S: Chinese herbs: a clinical review of Astragalus, Ligusticum, and Schizandrae. Altern Med Rev 1998, 3:338-344.

10. Soković M, Glamočlija J, Marin PD, Brkić D, van Griensven LJ: Antibacterial effects of the essential oils of commonly consumed medicinal herbs using an in vitro model. Molecules 2010, 15:7532-7546.

11. Al-Momani W, Abu-Basha E, Janakat S, Nicholas RA, Ayling RD: In vitro antimycoplasmal activity of six Jordanian medicinal plants against three Mycoplasma species. Trop Anim Health Prod 2007, 39:515-519.

12. Muraina IA, Adaudi AO, Mamman M, Kazeem HM, Picard J, McGaw L, Eloff JN: Antimycoplasmal activity of some plant species from northern Nigeria compared to the currently used therapeutic agent. Pharm Biol 2010, 48:1103-1107.

13. Guo FC, Kwakkel RP, Williams BA, Li WK, Li HS, Luo JY, Li XP, Wei YX, Yan ZT, Verstegen MW: Effects of mushroom and herb polysaccharides, as alternatives for an antibiotic, on growth performance of broilers. Br Poult Sci 2004, 45:684-694.

14. Motohashi N, Wakabayashi H, Kurihara T, Fukushima H, Yamada T, Kawase M, Sohara Y, Tani S, Shirataki Y, Sakagami H, et al: Biological activity of barbados cherry (acerola fruits, fruit of Malpighia emarginata DC) extracts and fractions. Phytother Res 2004, 18:212-223.

15. Jiménez-Medina E, Garcia-Lora A, Paco L, Algarra I, Collado A, Garrido F: A new extract of the plant Calendula officinalis produces a dual in vitro effect: cytotoxic anti-tumor activity and lymphocyte activation. BMC Cancer 2006, 6:119.

16. Hearst C, McCollum G, Nelson D, Ballard LM, Millar BC, Goldsmith CE, Rooney PJ, Loughrey A, Moore JE, Rao JR: Antibacterial activity of elder
(Sambucus nigra L.) flower or berry against hospital pathogens. J Med Plant Res 2010, 4:1805-1809.

17. Cowan MM: Plant products as antimicrobial agents. Clin Microbio/ Rev 1999, 12:564-582.

18. Andrews JM: Determination of minimum inhibitory concentrations. J Antimicrob Chemother 2001, 48(Suppl 1):5-16.

19. Meur SK, Sikdar A, Srivastava NC, Srivastava SK: Rapid photometric assay of growth of Mycoplasma mycoides subsp. capri. J Appl Bacterio/ 1989, 66:301-302.

20. Sanders DW, Weatherwax P, McClung LS: Antibacterial Substances from Plants Collected in Indiana. J Bacteriol 1945, 49:611-615.

21. Alexopoulos A, Kimbaris AC, Plessas S, Mantzourani I, Theodoridou I, Stavropoulou E, Polissiou MG, Bezirtzoglou E: Antibacterial activities of essential oils from eight Greek aromatic plants against clinical isolates of Staphylococcus aureus. Anaerobe 2011, 17:399-402.

22. Thomsen PS, Jensen TM, Hammer KA, Carson CF, Mølgaard P, Riley TV: Survey of the antimicrobial activity of commercially available Australian tea tree (Melaleuca alternifolia) essential oil products in vitro. J Altern Complement Med 2011, 17:835-841.

23. Antunes NT, Tavío MM, Assunção P, Rosales RS, Aquili V, de laFé C, Poveda JB: In vitro susceptibilities of field isolates of Mycoplasma mycoides subsp. mycoides large colony type to 15 antimicrobials. Vet Microbio/ 2007, 119:72-75.

24. Al-Momani W, Nicholas RA, Janakat S, Abu-Basha E, Ayling RD: The in vitro effect of six antimicrobials against Mycoplasma putrefaciens. Mycoplasma mycoides subsp. mycoides LC and Mycoplasma capricolum subsp. capricolum isolated from sheep and goats in Jordan. Trop Anim Health Prod 2006, 38:1-7.

25. Iwasa K, Kamigauchi M, Sugiura M, Nanba H: Antimicrobial activity of some 13-alkyl substituted protoberberinium salts. Planta Med 1997, 63:196-198.

26. Patil RS, Kokate MR, Kolekar SS: Bioinspired synthesis of highly stabilized silver nanoparticles using Ocimum tenuiflorum leaf extract and their antibacterial activity. Spectrochim Acta A Mol Biomol Spectrosc 2012, 91C:234-238.

27. Fronza M, Heinzmann B, Hamburger M, Laufer S, Merfort I: Determination of the wound healing effect of Calendula extracts using the scratch assay with 3 T3 fibroblasts. J Ethnopharmacol 2009, 126:463-467.

28. Klouchek-Popova E, Popov A, Pavlova N, Krŭsteva S: Influence of the physiological regeneration and epithelialization using fractions isolated from Calendula officinalis. Acta Physiol Pharmacol Bulg 1982, 8:63-67.

29. Parente LM, Lino Júnior RS, Tresvenzol LM, Vinaud MC, de Paula JR, Paulo NM: Wound Healing and Anti-Inflammatory Effect in Animal Models of Calendula officinalis L. Growing in Brazil. Evid Based Complement Alternat Med 2012, 2012:375671.

30. Parente LM, Andrade MA, Brito LA, Moura VM, Miguel MP, Lino-Júnior RS, Tresvenzol LF, Paula JR, Paulo NM: Angiogenic activity of Calendula officinalis flowers L. in rats. Acta Cir Bras 2011, 26:19-24.

31. Fuchs SM, Schliemann-Willers S, Fischer TW, Elsner P: Protective effects of different marigold (Calendula officinalis L.) and rosemary cream preparations against sodium-lauryl-sulfate-induced irritant contact dermatitis. Skin Pharmacol Physiol 2005, 18:195-200.

32. Chatterjee A, Yasmin T, Bagchi D, Stohs SJ: Inhibition of Helicobacter pylori in vitro by various berry extracts, with enhanced susceptibility to clarithromycin. Mol Cell Biochem 2004, 265:19-26.

33. Lusher $P$, Denyer SP, Hugo WB: A note on the effect of dilution and temperature on the bactericidal activity of potassium sorbate. $J$ App/ Bacteriol 1984, 57:179-181.

34. Lambert RJ, Skandamis PN, Coote PJ, Nychas GJ: A study of the minimum inhibitory concentration and mode of action of oregano essential oil, thymol and carvacrol. J Appl Microbiol 2001, 91:453-462.

35. Peñalver $P$, Huerta B, Borge $C$, Astorga R, Romero R, Perea A: Antimicrobial activity of five essential oils against origin strains of the Enterobacteriaceae family. APMIS 2005, 113:1-6.

36. Akgül A, Kivanç M: Inhibitory effects of selected Turkish spices and oregano components on some foodborne fungi. Int J Food Microbiol 1988, 6:263-268.

37. Essawi T, Srour M: Screening of some Palestinian medicinal plants for antibacterial activity. J Ethnopharmacol 2000, 70:343-349.

doi:10.1186/1472-6882-12-169

Cite this article as: Arjoon et al.: In Vitro efficacy of antimicrobial extracts against the atypical ruminant pathogen Mycoplasma mycoides subsp. capri. BMC Complementary and Alternative Medicine 2012 12:169. 